\section{7 gra (2) PREPARED FOR THE U.S. DEPARTMENT OF ENERGY, UNDER CONTRACT DE-AC02-76-CHO-3073}

PPPL-2785

U'C-420,426,427

\title{
PHENOMENOLOGY OF HIGH ENSITY DISRUPTIONS IN THE TFTR TOKAMAK
}

\author{
BY
}

E.D. FREDRICKSON, ET AL

January 1992

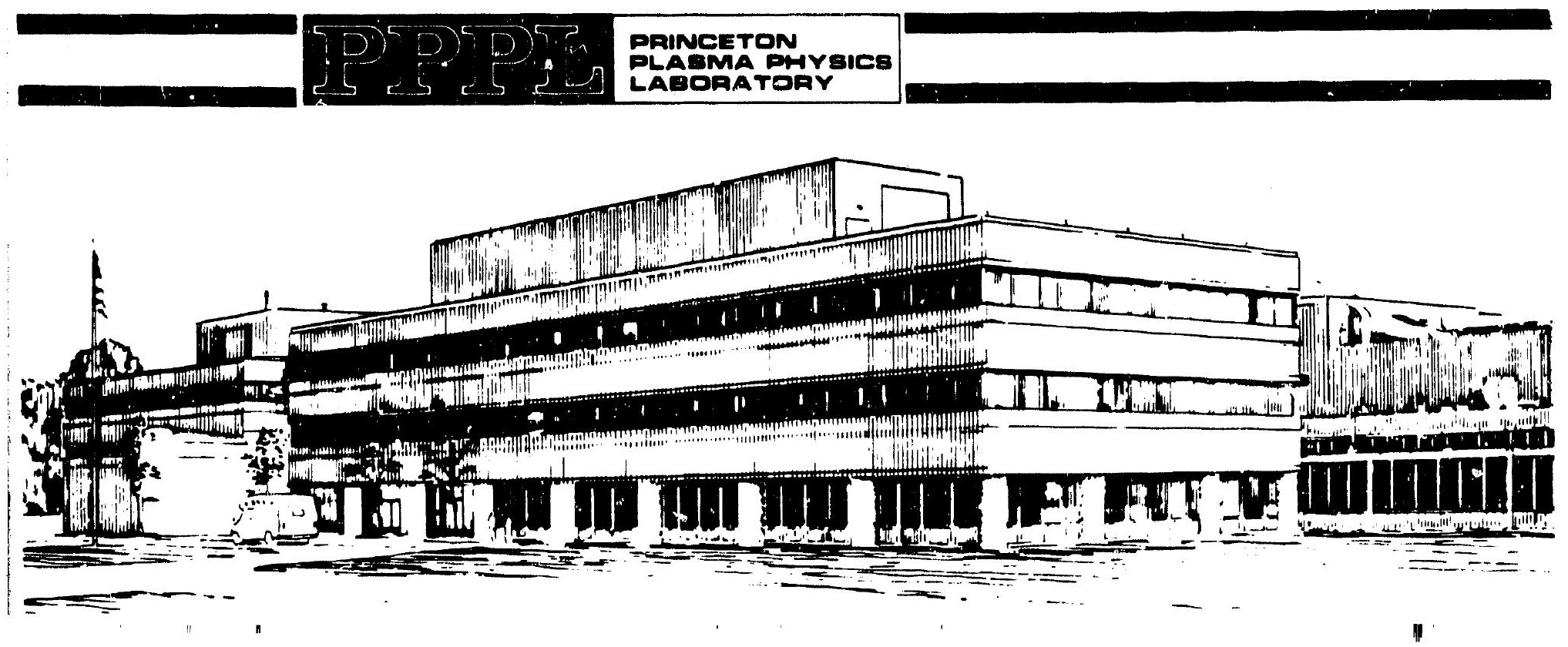




\section{NOTICE}

This report was prepared as an account of work sponsored by an agency of the United States Government. Neither the United States Government nor any agency thereof, nor any of their employees, makes any warranty, express or implied, or assumes any legal liability or responsibility for the accuracy, completeness, or usefulness of any information, apparatus, product, or process disclosed, or rupresents that its use would not infringe privately owned rights. Reference herein to any specific commercial produce, process, or service by trade name, trademark, manufacturer, or otherwise, does not necessarily constitute or imply its endorsement, recommendation, or favoring by the United States Government or any agency thereof. The views and opinions of authors expressed herein do not necessarily state or reflect those of the United States Government or any agency thereof.

\section{NOTICE}

This report has been reproduced directly from the best available copy.

Available to DOE and DOE contractors from the:

Office of Scientific and Technical Information P.O. Box 62

Oak Ridge, TN 37831 ; Prices available from (615) 576-8401.

Available to the public from the:

National Technical Information Service

U.S. Department of Commerce

5285 Port Royal Road

Springfield, Virginia 22161

703-487-4650 


\title{
Phenomenology of High Density
}

\section{Disruptions in the TFTR Tokamak}

E. D. Fredrickson, K. McGuire, M. Bell, C. E. Bush,

A. Cavallo, R. Budny, A. Janos, D. Mansfield, Y. Nagayama, H. Park, J. Schivell, G. Taylor, and M. C. Zarnstorff Princeton Plasma Physics Laboratory

Princeton University, Princeton, NJ 08543

\author{
J. Drake and R. Kleva \\ University of Maryland, College Park, Maryland
}

\begin{abstract}
Recent studies on TFTR of high density disruptions have made significant advances in closing the gap between theoretical models of disruptions and the experimental data. For the first time, an $(m, n)=(1,1)$ 'cold bubble' precursor to the high density disruptions has been experimentally observed. The precursor resembles the 'vacuum bubble' model of disruptions first proposed by Kadomtsev and Pogutse.
\end{abstract}


Disruption control or avoidance is an important engineering issue for the present generation of tokamaks (JET, TFTR, and JT-60) and presents even more stringent design constraints for the next generation of tokamaks, i.e., ITER. To compound the problem, the next generation of tokamaks will also have to operate near the present empirically determined density and $\beta$ disruption limits to achieve their operational goals. Understanding the disruption mechanism is of vital importance to the future of the fusion energy program. For the first time, the presence of an $(m, n)=(1,1)$ 'vacuum bubble' precursor ${ }^{1}$ to the major disruption at high density has been observed experimentally. This kink instability has been proposed by Kadomtsev and Pogutse as a possible mechanism for the major disruption. The instability requires a very low shear region within the $q=1$ surface for the kink to be unstable. ${ }^{2-4}$

Disruptions at high density occurring both during normal plasma operation and during limiter conditioning have been studied in the TFTR tokamak. The pre-disruptive phase of disruptions at high density on TFTR follow the now well known characteristic pattern which has been observed previously on other machines. ${ }^{5,6}$ The disruptions are preceeded by the collapse of the 
edge electron temperature accompanied by multiple partial and minor disruptions. Sawteeth may be present during this period; if so the sawtooth inversion radius increases, consistent with the model $^{3,5,6}$ that the current profile is contracting. A previously unreported feature is that concurrent with the edge collapse, the electron temperature within the $q=1$ surface becomes very flat and remains so throughout this phase. An example of the edge temperature collapse and central flattening of the electron temperature during the predisruptive phase is shown in Fig. 1.

Three distinct types of disruptions have been identified ${ }^{5}$ (excluding the internal disruption or sawtooth). All are marked by abrupt changes in the shape of the electron temperature profile. The first type is the partial or off-axis disruption, a number of which may be observed in the traces of electron temperature v's. time between 4.55 and $4.65 \mathrm{sec}$ in Fig. 1. One of these partial disruptions is shown in more detail in Fig. 2. As can be seen, the partial disruption flattens the electron temperature in an anular ring, affecting the central electron temperature only on a diffusive timescale. In the partial disruptions studied to date, the flattening has occurred near the location of the $q=2$ surface. 
For detailed examples of minor and major disruptions, we will look at a high density ohmic plasma. This discharge is near the Greenwald density limit $^{7}$ [which for circular plasmas can be written as $\langle n\rangle /\langle J\rangle \approx 10^{20}$ $\left(\mathrm{MA} \mathrm{m}^{-1}\right.$ ] (Fig. 3). At about $0.8 \mathrm{sec}$ the plasma became detached ${ }^{8}$ from the limiter and remained detached until the disruption. The predisruptive phase begins at $3 \mathrm{sec}$ with the onset of partial and minor disruptions and a further collapse of the edge electron temperature. This phase has sawteeth and partial disruptions as well as a minor disruption at $3.332 \mathrm{sec}$ (Fig. 3). The electron temperature profile over the central region of the plasma was determined from the electron cyclotron emission (ECE) measured with the Grating Polychromator (GPC) ${ }^{9}$ at $200 \mu$ sec intervals. The GPC was cross calibrated to the ECE radiometer. ${ }^{10}$

The minor disruption in Fig. 3 begins with a growing hollowness of the electron temperature profile on the midplane (Fig. 4). It is found that this hollowness is due to an $(\mathrm{m}, \mathrm{n})=(1,1)$ 'cold bubble' moving into the plasma core. The precursor continues to grow until the disruption takes place which flattens the electron temperature across the center of the plasma. This event resembles a sawtooth crash, but the inversion and mixing radii are much 
larger. For the example shown in Fig. 4, the inversion radius is $0.28 \mathrm{~m}$ (near $\mathrm{q}=1.5$ ) and the mixing radius extends nearly to the $\mathrm{q}=3$ surface at $\mathrm{r}=0.49 \mathrm{~m}$. The internal inductance, as determined from the measurement of $\Lambda\left(\equiv \beta_{p o l}^{\text {equil }}+l_{i} / 2\right)$ remains unchanged (Fig. 3). Following the disruption, the edge temperature drops and the profile peaks up to a shape similar to that before the disruption, including the flattened region within the $q=1$ surface (profile 'd'). The sawtooth inversion radius and the region of flatness in the central $T_{e}$ profile following the minor disruption are only slightly reduced compared to that before the disruption. Thus, although the electron temperature is flattened out to the $\mathrm{q}=3$ surface, there is no evidence for a similar redistribution of the plasma current.

The major disruption begins in much the same way as the minor disruption, with the rapid growth of a 'cold bubble' $\mathrm{m}=1$ mode (Figs. 3 and 5). Fast data from the horizontally viewing $X$-ray camera is available at the time of this major disruption, and it shows a vertically asymmetric collapse of the soft X-ray emissivity profile, supporting the model of the cold bubble shape for the precursor. The growth of the precursor is about 5 times faster for the major disruption $\left(\gamma \approx 5 \times 10^{3} s^{-1}\right)$ than for the minor disruption 
$\left(\gamma \approx 1 \times 10^{3} s^{-1}\right)$. While the central electron temperature is even hotter at the time of the major disruption, the temperature beyond the $q=1.5$ surface is lower.

At the end of the crash phase the $\Lambda$ is seen to decrease sharply (Fig. 3), suggesting a redistribution of plasma current. ${ }^{11,12}$ (In this figure, the relative timing between the temperature and magnetics diagnostics was determined from comparison of the synchronized fast soft x-ray camera and Mirnov coil data.) The change in $\Lambda$ from 1.15 to 0.85 is consistent with a flattening of the current profile to the $q \approx 3$ radius (the $\beta_{p o l}$ is $\approx 0.1$ at this time). This suggests that in this case either the $m=1$ mode, or modes excited during the crash, led to a reconnection or a destruction of the magnetic flux surfaces and a broadening of the current profile. The central electron temperature remains about $1 \mathrm{kel}$ for several msec following the major disruption; then the temperature abruptly drops to less than $100 \mathrm{eV}$ and the current quench phase begins. It is not known at this time what is responsible for this final temperature drop.

The internal $(\mathrm{m}, \mathrm{n})=(1,1)$ cold bubble precursor structure has also been seen in disruptions at moderate density and low $q(a)(\approx 2.5)$. The density 
for this case is well below the Greenwald limit, but the phenomenology of the disruption appears similar to those studied above. Again, the edge electron temperature had collapsed and the central electron temperature profile was very flat, implying very rapid thermal transport (and possibly low shear) within the $\mathrm{q}=1$ radius. With the fast ECE data from the grating polychromator and the soft $\mathrm{X}$-ray data it was possible to observe a cold bubble moving downward (at this ioroidal location) into the core of the plasma at a speed of $2 \times 10^{6} \mathrm{~m} / \mathrm{s}$ (Figs. $6 \mathrm{a}$ and $6 \mathrm{~b}$ ). The growth rate of the precursor mode, inferred from this measurement, is $\gamma \approx 1 \times 10^{4} \mathrm{~s}^{-1}$.

While $(\mathrm{m}, \mathrm{n})=(2,1)$ and $(3,1)$ precursors have been observed before some disruptions on TFTR, direct evidence for them is often lacking, as it is in the present examples. We cannot exclude the possibility that such modes commonly exist in a locked state prior to disruptions; however, that would suggest that the mode retain an amplitude larger than the locking threshold amplitude ${ }^{13,14}$ through partial and minor disruptions.

Thus, in both high density and high current discharges on TFTR the temperature profile evolves to a 'tophat configuration. In such temperature profiles the close proximity of the $q=1$ surface and the cold edge plasma 
allows the $(1,1)$ mode to reconnect in the cold plasma region and inject this cold plasma into the center of the plasma column. The possible nature of the instability and why it may lead to major or minor disruptions are discussed below.

A cold plasma bubble can be injected into the plasina column by either the external ${ }^{1-4}$ or internal ${ }^{15}(1,1)$ kink if the central q profile is close to unity and $q$ falls below unity off axis. The details of the $q$ profile in the these experiments are unknown. With neoclassical resistivity the flat $T_{e}$ profiles measured in the experiment should actually produce a peaked $J(r)$ profile, unless the mechanism which maintains the flat central $T_{e}(r)$ also flattens $J(r)$. As a working hypothesis, we assume that $q(r)$ is flat and that the bubble is produced by the magnetic reconnection over an annular ring of width $\delta r$ locáted at a radius $r_{s}$ (with $\delta r \ll r_{s}$ ). An estimate of $\delta r$ can be obtained from the radius $r_{b}$ of the cold bubble, $\delta r=r_{b}^{2} / 2 r_{s}$. Taking $r_{b}$ as the radius of the bubble at the half depth and $r_{s}$ the radius of the cold plasma shoulder on the $T_{e}$ profile, we find that for the minor disruption (Fig. 4) $\delta r \sim 0.037 m$ while for the major disruption $\delta r \sim 0.021 m$. Thus, the reconnection layers are quite narrow. 
There is a continuous transition between the external and internal $(1,1)$ kink based on the resistivity of the plasma at the $q=1$ surface. When the resistivity is small, the plasma dynamics at the $q=1$ surface limit the rate of growth of the bubble to the Sweet-Parker rate. ${ }^{16}$ The 'frozen-in' condition which is valid everywhere except in a narrow layer around the rational surface guarantees that $q$ will be equal to 1.0 within the bubble after reconnection is complete. ${ }^{16}$ When the resistivity is very large, the plasma in the vicinity of the rational surface acts as a vacuum and no longer controls the rate of reconnection. The instability is essentially an external kink. The 'vacuum bubble' injected into the plasma as a result of the instability carries little or no current and thus $q$ will be greater than 1.0 within the bubble. ${ }^{1,3,4,17}$ The transition of the $(1,1)$ kink from an internal to an external mode depends on the formation time of the bubble $\tau_{b}$ compared with the flux diffusion rate across the reconnection zone $\tau_{R}=4 \pi(\delta r)^{2} / \eta c^{2}$. For the minor disruption in Fig. $4, \tau_{b} \approx 0.8 \mathrm{msec}$ while $\tau_{K} \approx 3.3 \mathrm{msec}$ (based on the $200 \mathrm{eV}$ edge temperature). Thus, since $\tau_{R} \gg \tau_{b}$, the mode in this case must be categorized as an internal kink. The internal kink produces a $q$ profile which is flat and close to unity. This conclusion is also consistent with the absence of a large change in the $\Lambda$, which would change significantly as a result of the 
modification of the current profile by the external kink. ${ }^{1,4,17}$

For the major disruption, $\tau_{b} \approx 0.2 \mathrm{msec}$ and $\tau_{R} \approx 0.34 \mathrm{msec}$ so that $\tau_{r} \sim$ $\tau_{b}$. Thus, the formation of the bubble in the case of the major disruption is driven by a quasi-external kink. The external kink produces a non-monotonic q profile in which $q(0)$ can be significantly greater than unity. Such a profile is unstable to a range of modes with $m \geq 2$ and leads to significant broadening and disruption of the current in a recent 3-D resistive MHD simulation of the density limit. ${ }^{3}$

\section{Summary}

The phenomenology of disruptions at high density has been studied on TFTR. While the global features of the pre-disruption phase on TFTR are found to be similar to what has been previously reported, a more detailed picture of the disruption mechanism has emerged from the fast electron temperature profile data. Previous work had suggested that the $(m, n)=(1,1)$ internal kink had played a role in the final disruption. ${ }^{5,6}$ The data from TFTR indicates that while the minor disruption may be caused by the internal kink driven cold plasma bubble, the major disruption may be triggered by a 'vac- 
uum bubble' as originally predicted by Kadomtsev and Pogutse. ${ }^{1}$ The rapid growth rate $\left(\gamma \geq 10^{3} \mathrm{sec}^{-1}\right)$ and the $(\mathrm{m}, \mathrm{n})=(1,1)$ character of the mode are extremely unfavorable to traditional cxternal feedback methods. ${ }^{18-20}$ However, maintenance of a sufficiently high edge temperature $(>200 \mathrm{eV})$ should prevent the external kink from developing and therefore inhibit the major disruption.

\section{Acknowledgments}

The authors would like to sincerely thank the TFTR group for their contributions to this work. We would also like to thank D. Monticello and J. Callen for useful discussions and suggestions. This work was supported by U.S. DoE Contract No. DE-AC02-76CHO-3073. 


\section{References}

${ }^{1}$ Kadomtsev, B. B. and Pogutse, O. P., Sov. Phys. JETP 38 (1974) 283.

${ }^{2}$ Monticello, D. A., White, R. B., and Rosenbluth, M. N., in Plasma Physics and Controlled Nuclear Fusion Research 1978 (Proc. 7th Int. Conf. Innsbruck, 1978), Vol. 1, IAEA, Vienna (1979) 605.

${ }^{3}$ Kleva, R. G. and Drake, J. F., Phys. Fluids B 3 (1991) 372.

${ }^{4}$ Dnestrovski, Y. N., Zakharov, L. E., Kostomorov, D. P., Kukushkin, A. C., and Suzdaltseva, L. F., pls'ma Zh. Tekh. Fiz. 1 , 45 (1975) [Sov. Tech. Phys. Lett. 1,18 (1975)].

${ }^{5}$ Tsuji, S., Nagayama, Y., Miyamoto, K., Kawahata, K., Noda, N., and Tanahashi, S., Nucl. Fusion 25 (1985) 305.

${ }^{6}$ Wesson, J., Gill, R. D., Hugon, M., et al., Nucl. Fusion 29 (1989) 641.

${ }^{7}$ Greenwald, M., Terry, J. L., Wolfe, S. M., Ejima, S., Bell, M. G., Kaye, S. M., and Neilson, G. H., Nucl. Fusion 28 (1988) 2199.

${ }^{8}$ Bush, C. E., Schivell, J., Strachan, J. D., et al, J. Nucl. Mater. 176 \& $177(1990) 786$. 
${ }^{9}$ Cavallo, A., Cutler, R. C., and McCarthy, M. P., Rev. Sci. Instrum. 59 (1988) 889.

${ }^{10}$ Taylor, G., Efthimion, P. C., McCarthy, M. P., Fredd, E., and Cutler, R. C., Rev. Sci. Instrum. 57 (1986) 1974.

${ }^{11}$ Hosea, J. C., Bobeldijk, C., Grove, D. J., in Proceedings of the 4th International Conference on Plasma Physics and Controlled Nuclear Fusion Research, Madison, Wisconsin (1971) Vol II 425.

${ }^{12}$ Hutchinson, I., Phys. Rev. Lett. 37 (1975) 338.

${ }^{13}$ Nave, M. F. F., Wesson, J. A., in Controlled Nuclear Fusion and Plasma Physics (Proc. 14th European Conference Madrid 1987) Vol. IID, Part III European Physical Society (1987) 1103.

${ }^{14}$ Snipes, J. A., Campbell, D. J., Haynes, P. S., et al. , Nucl. Fusion 28 (1988) 1085.

${ }^{15}$ Kleva, R., Drake, J. and Denton, R., Phys. Fluids 30 (1987) 2119.

${ }^{16}$ Kadomtsev, B. B., Fiz. Plazmy Vol. I (1975) 710. 
${ }^{17}$ Rosenbluth, M. N., Monticello, D. A., Strauss, H. R., and White, R. B., Phys. Fluids 19 (1976) 1987.

${ }^{18}$ Bol, K., Cecchi, J. L., Daughney, C. C., et al., in Plasma Physics and Controlled Nuclear Fusion Research 1974 (Proc. 5th Int. Conf. Tokyo, 1974), Vol. 1 IAEA, Vienna (1975) 401.

${ }^{19}$ Arsenin, V. V., Artemenkov, L. I., and Ivanov, N. V., et al., in Controlled Fusion and Plasma Physics (Proc. 8th Eur. Conf. Prague, 1977), Vol. 1, European Physical Society (1977) 3.

${ }^{20}$ Morris, A. W., Arshad, S., Balkwill, C., et al. , in Controlled Fusion and Plasma Physics (Proc. 16th Eur. Conf. Venice, 1989) 489. 


\section{List of Figures}

Fig. 1. Electron temperature profiles at selected times during the predisruptive phase of a high density disruption showing the collapse of the edge electron temperature. [Other parameters for this shot were $q(a)=5$, $\left\langle n_{\mathrm{e}}>\approx 8 \times 10^{19} / \mathrm{m}^{3}, \mathrm{a}=0.9 \mathrm{~m}, \mathrm{R}=2.55 \mathrm{~m}, I_{P}=1.7 \mathrm{MA}\right.$ and $B_{T}=4.6$ Tesla.]

Fig. 2. Detail of a partial disruption during the predisruptive phase of the plasma in Fig. 1.

Fig. 3. Global waveforms showing the plasma current, central electron temperature, line integrated electron density and internal inductance for an ohmic high der sity disruption. [Other parameters for this shot were $q(a) \approx$ $9,<n_{\mathrm{e}}>\sim 2.5 \times 10^{19} / \mathrm{m}^{3}, \mathrm{a}=0.8 \mathrm{~m}, \mathrm{R}=2.45 \mathrm{~m}, I_{P}=0.7 M A$ and $B_{T}=$ 4.0 Tesla.]

Fig. 4. Electron temperature vs. time and major radius through the minor disruption of the shot in Fig. 3.

Fig. 5. Electron temperature vs. time and major radius through the major disruption of the shot in Fig. 3.

Fig. 6a. Profiles of the electron temperature just prior to the major 
disruption of a low $\mathrm{q}(\mathrm{a})$ shot. [Other parameters for this shot were $q(a)=$ $2.5, \mathrm{a}=0.8 \mathrm{~m},<n_{\mathrm{e}}>\sim 4.5 \times 10^{19} / \mathrm{m}^{3}, \mathrm{R}=2.45 \mathrm{~m}, I_{P} \sim 2.5 M A$ and $B_{T}=$ 5.2 Tesla.]

Fig. 6b. Profiles of the chord integrated soft $\mathrm{x}$-ray emissivity. 

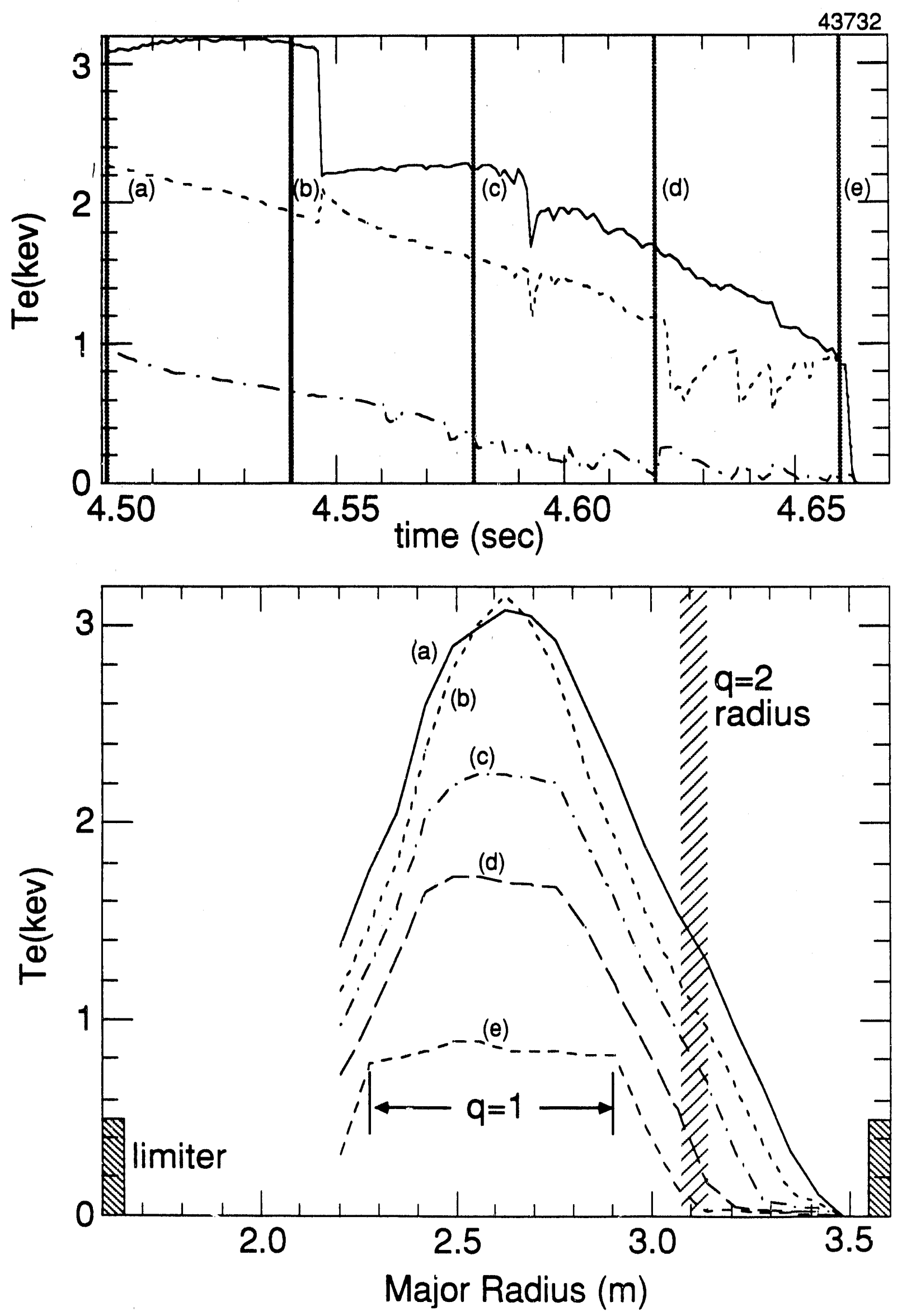

Fig. 1 

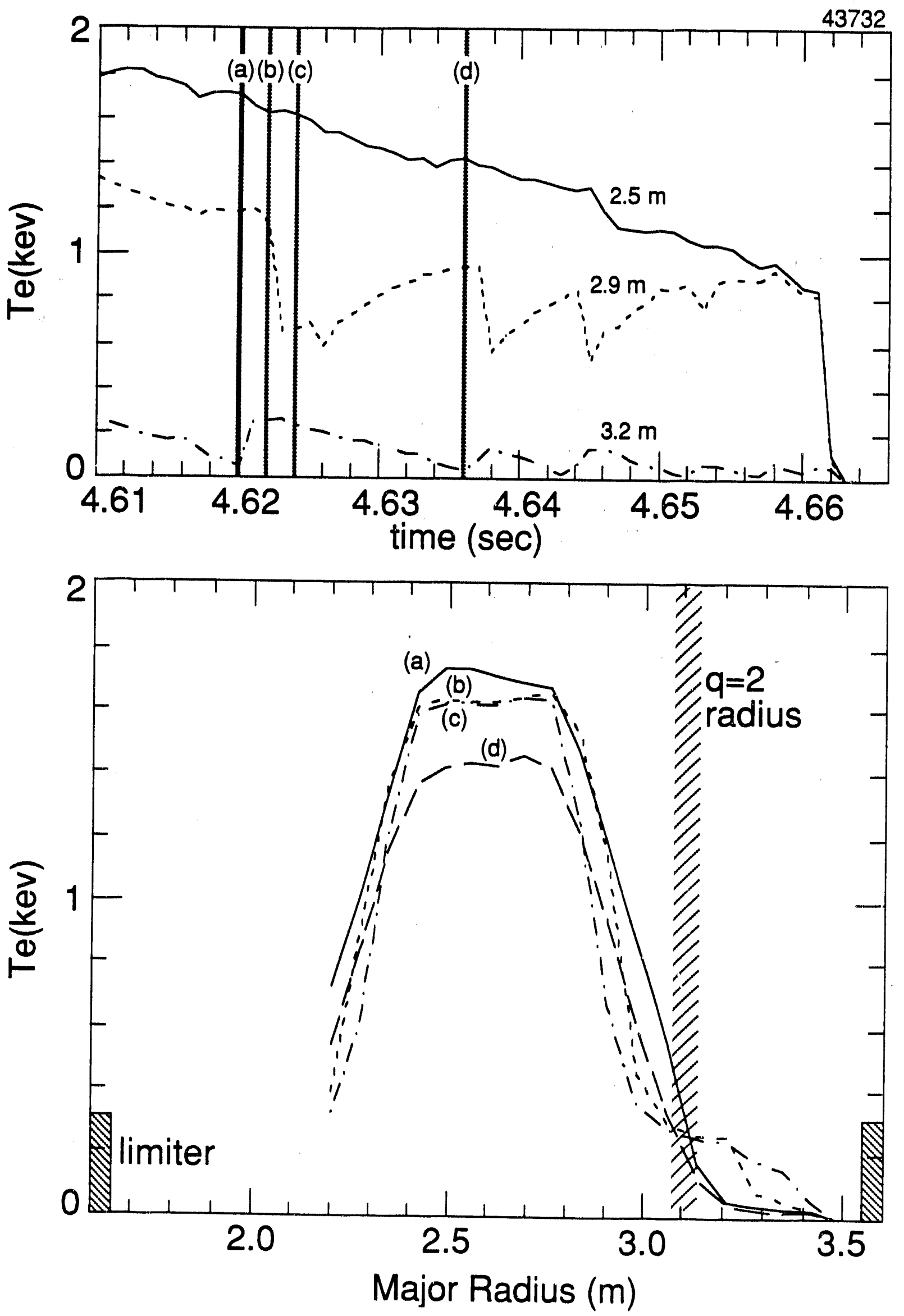

Fig. 2 

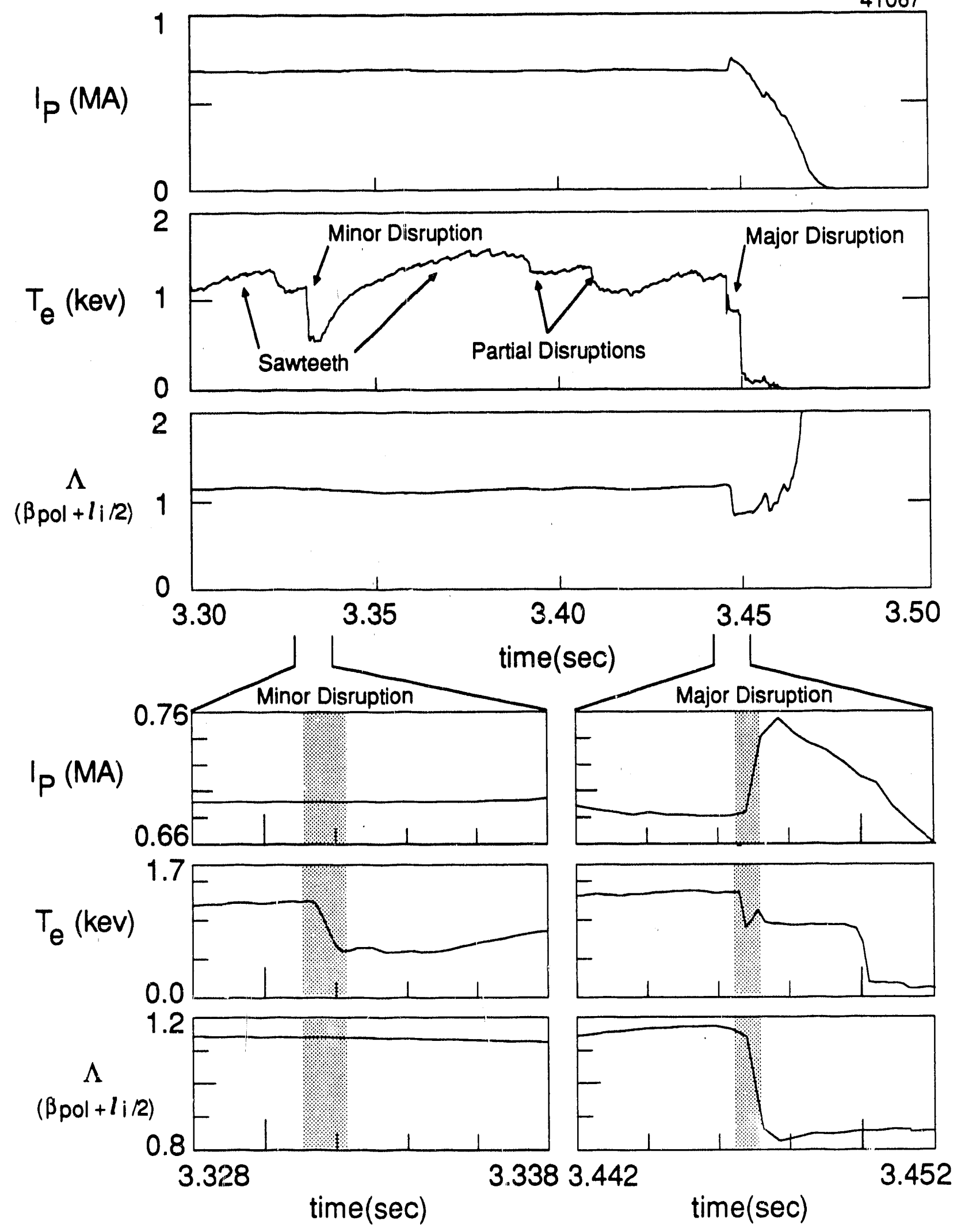

Fig. 3 

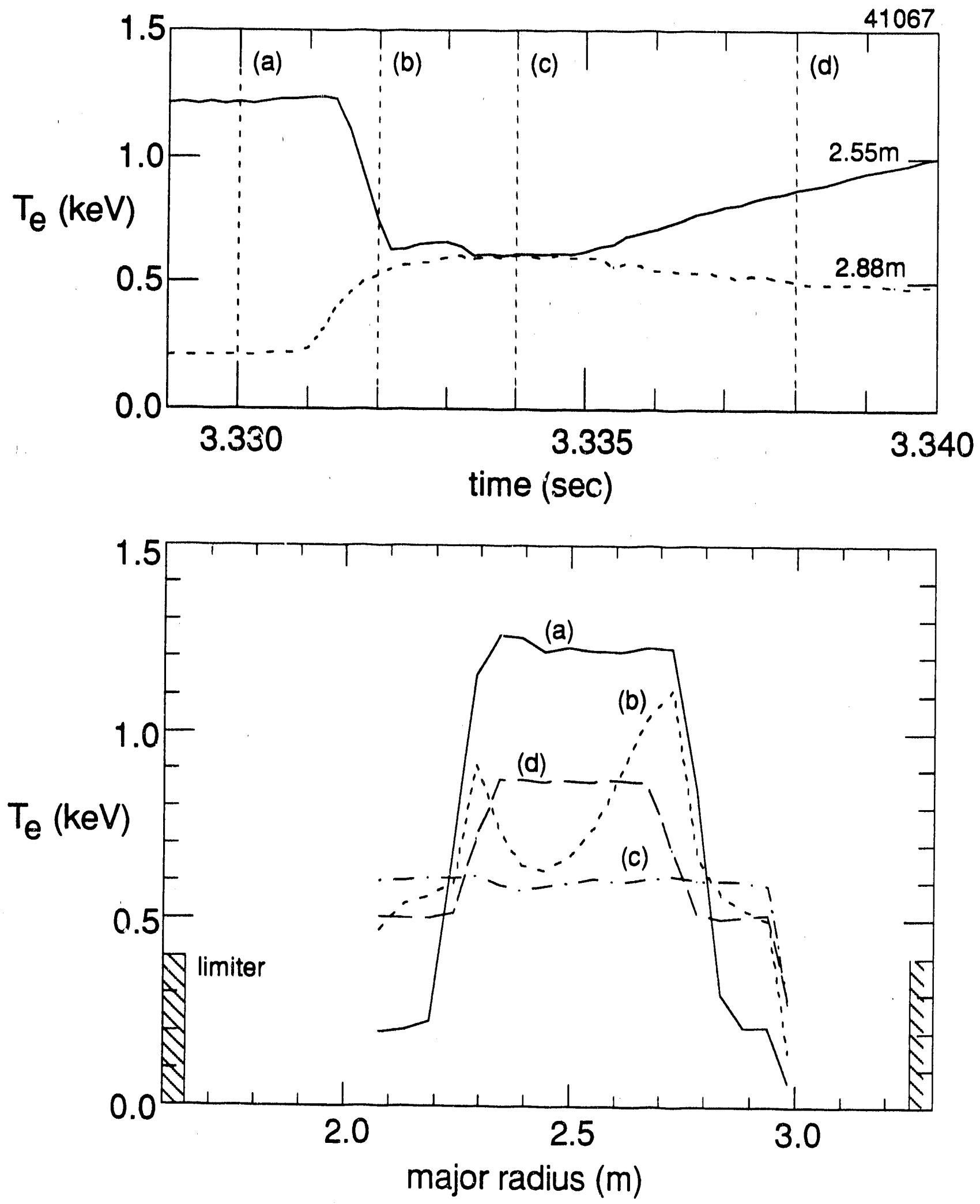

Fig. 4 

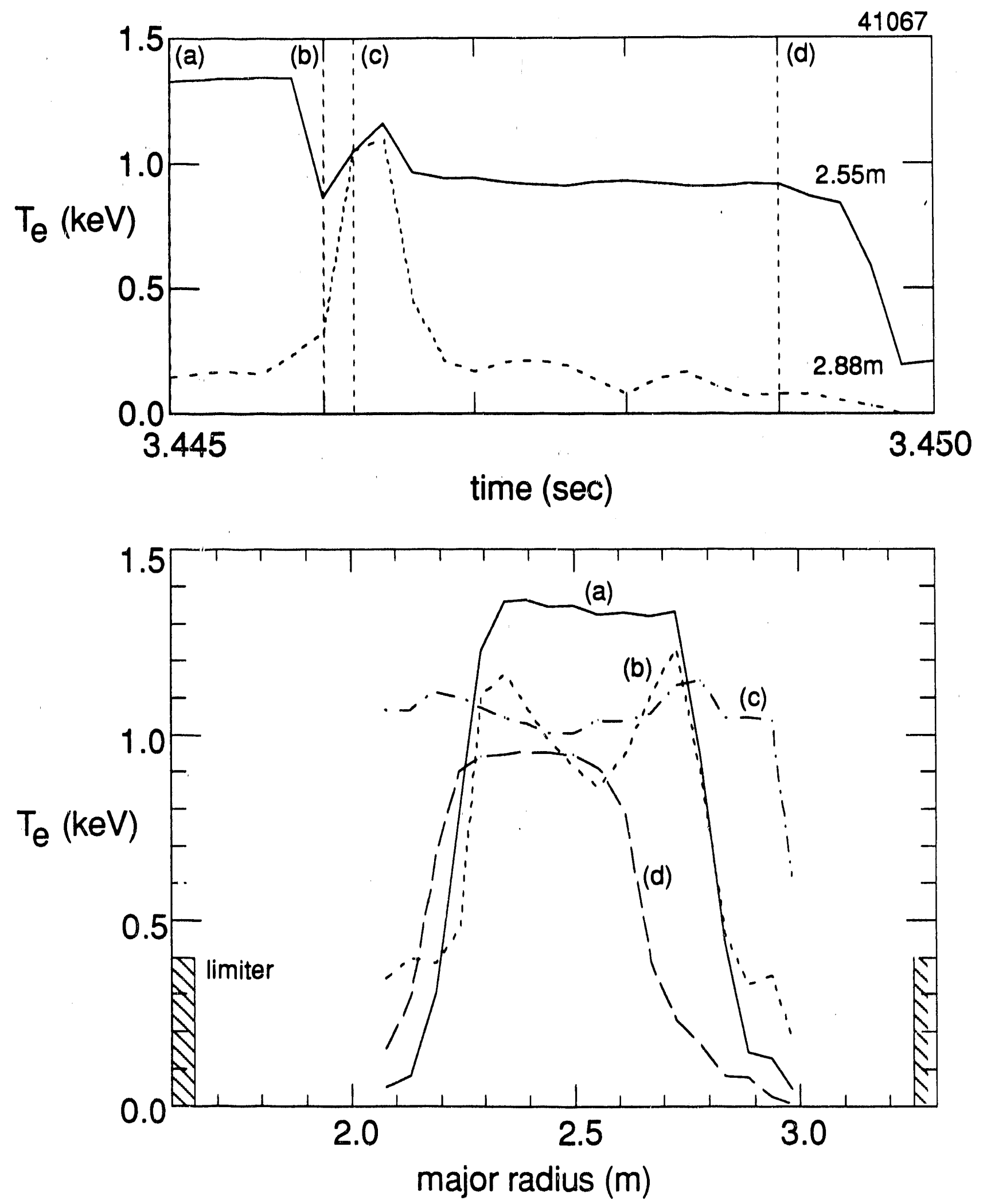

Fig. 5 

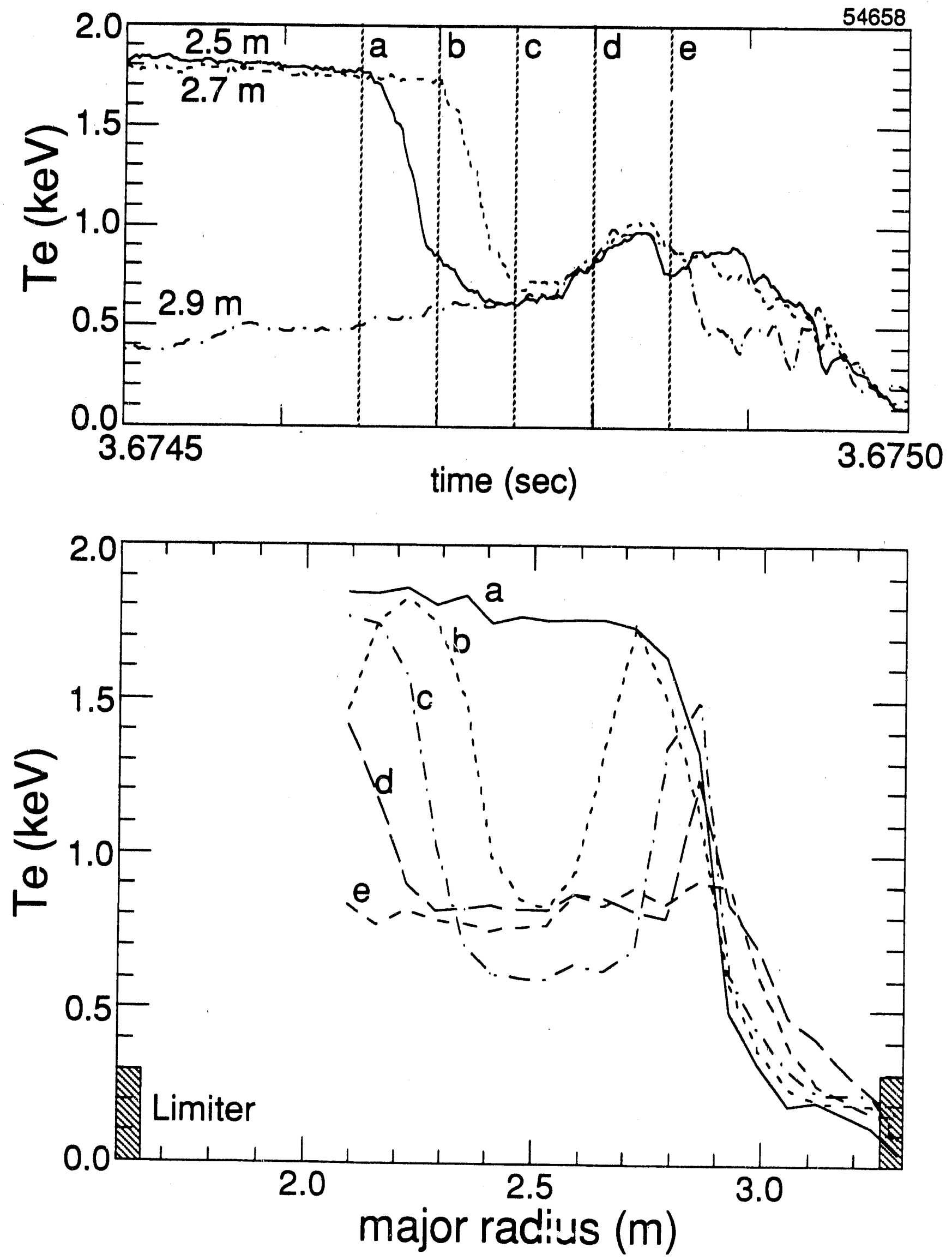

Fig. $6 a$ 


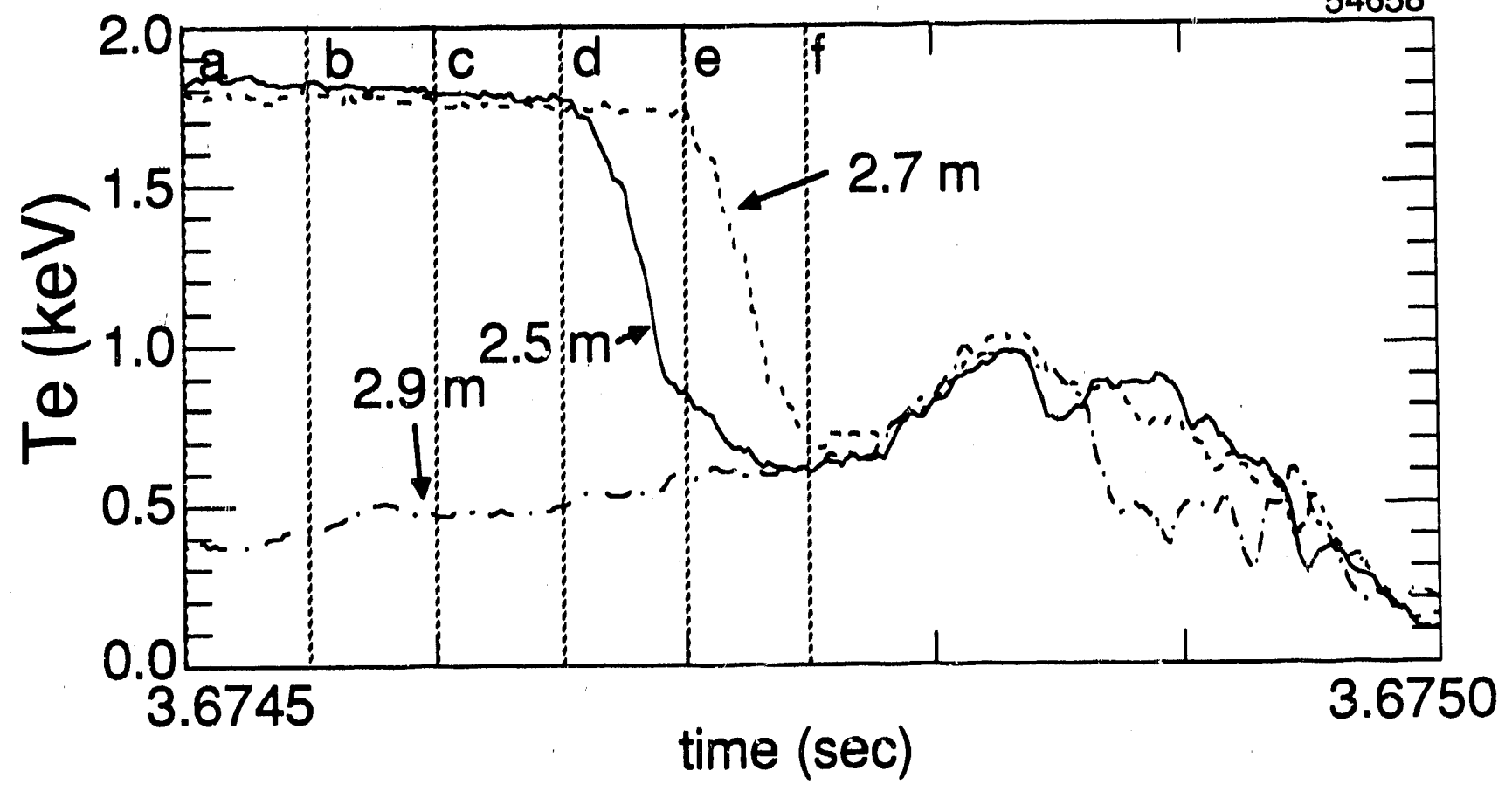

54658

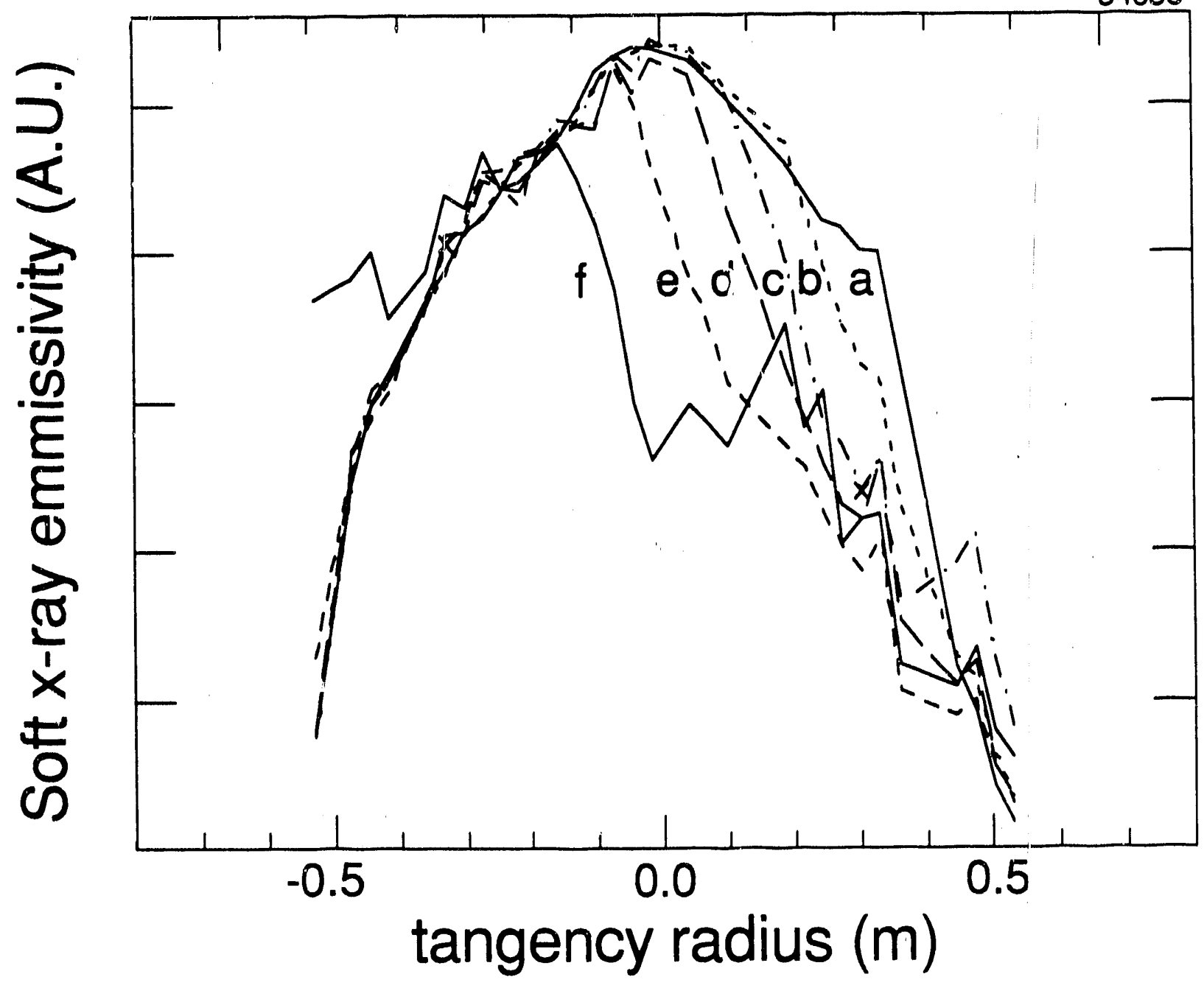

Fig. 6b 
Dr. F. Pecloni, Univ, of Wollongong, AUSTRALLA

Prot. M.H. Bremnen, Univ, of Sydney, AUSTRALLA

Plasma Rosearch Lob., Austration Nat. Univ., AUSTRALIA

Prot. I.R. Jones, Findore Univ, AUSTRALLA

Prot. F. Cep, Inst for Theoretical Phyeics, AUSTRIA

Prof. M. Haindier, Institut vor Theoretiechs Phyelk, AUSTALA

Prol. M. Coosems, Adsonomicen Insturt, BELGIUM

Ecolo Royes Muming, bo Phy. Plasmas, BELGIUM

Commiscion-Europen, DG. XIFFucion Prog., BELGIUM

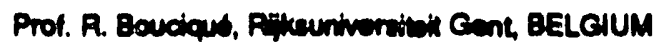

Dr. P.H. Sakenake, instrus Fiaica, BRUZLL

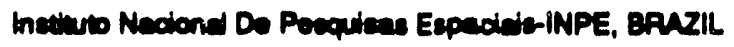

Documents Orices, Abonic Energy of Cened Ld., CANAOA

Dr. M.P. Bechyndd, MPB Technolocies, Inc., CANADA

Dr. H.M. Skereoperd, Univ. of Sackatchemen, CANAOA

Prof. J. Telchmem, Univ. of Montred, CANADA

Prot. S.R. Sncenivaen, Univ. of Celgary, CANAOA

Prof. T.W. Johnton, INRSEEnevie, CANADA

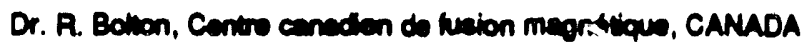

Dr. C.R. Jumes, Univ. of Aberta, CANADA

Dr. P. Luthe, Komencktho Unineresten, CZECHOSLOVAKIA

The Librerian, CUham Luboratory, ENCLAND

Librery, R31, Ruthertord Appleten Leboresory, ENCLAND

Mrs. S.A. Hutchineon, JET Librey, ENGLAND

Dr. S.C. Shama, Univ. of South Pecific, FWI ISLANDS

P. Munomen, Univ. of Haleindd, FINLAND

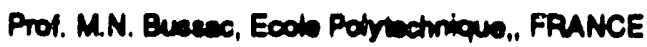

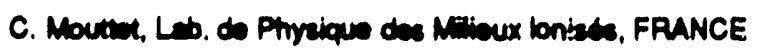

J. Radol, CEMCADARACHE - BAt SO6, FRANCE

Prot. E. Economou, Unir. of Crew, GREECE

Mr. C. Rinnd, Univ. of loaming, GREECE

Dr. T. Mud, Aasdemy Balographic Ser., HONO KONO

Preprint Librey, Hungarien Acatermy of Sa., HUNGARY

Dr. B. Descupte, sah met of Nuclaer Ptyrics, INDIA

Dr. P. Kew, hat. for Pleama Research, INDLA

Dr. P. Rowerney, lered het of Technology, ISPAEL

Librerien, Intemationd Cenver for Theo Ptyyice, ITALY

Mias C. Do Pab, Aseodiczions EURATOAAENEA, ITALY

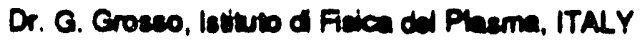

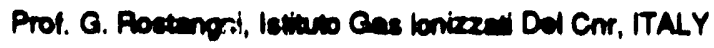

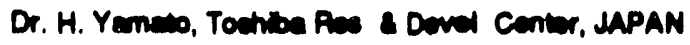

Prof. I. Kewakemi, Mtroshima Univ., JAPAN

Prof. K. Nishikewwa, Hiroahime Univ., LAPAN

Director, Jepen Atomk Energy Rosearch Inst, JAPAN

Prot. S. Itoh, Kyuahu Univ., JAPAN

Rasemen into. Ct., Nationd Instit for Fueion Scionce, JAPAN

Prof. S. Tenatia, Kyoto Univ., JAPAN

Libren, Kyoto Univ., LAPAN

Prot. N. Inow, Univ. of Tolyo, LAPAN

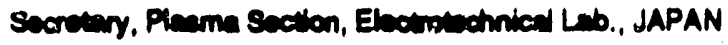

S. Mori, Techinid Advicor, MAEP, MPAN

Dr. O. Mind, Kumanots Inst of Technobogy, JAPAN

J. Hyeon-Boot, Korea Abomic Enoroy Racearch mst, KOREA

D.I. Choi, Tho Korma Adv, Inst of Sal. Tech., KOREA

Prot. 8.8. Ulay, Uniw. of Weikato, NEW ZEALAND

Inte of Phyrics, Chineed Acod Sd PEOPLE'S REP. OF CHINA

Lierery. Inal of Piama Phyeics, PEOPLE'S REP. OF CHINA

Taingtur Univ. Litrery, PEOPLE'S REPUBLC OF CHINA

2. U, S.W. Int Phyedes, PEOPLE'S REPUBLIC OF CHINA

Prot. J.A.C. Cebrd, Inatus Superior Toenico, POPTUGAL

Dr. O. Perrus, Al I CUzA Univ., ROMMnia

Dr. J. co Vimon, Fution Studies, AEC, S. AFPICA

Prot. M.A. Hemberg, Univ, of Nated, S. AFRICA

Prot. D.E. Km, Paheno inat. of Sa. a Treh., SO. KOAEA

Prot. C.I.E.M.A.T, Fueion Diviaion Librery, SPAN

Dr. L Similo, Unio. of UMEA, SWEDEN

Librery, Royd inat of Technology, SWEDEN

Prot. H. Whelmecon, Chamers Univ. of Tech., SWEDEN

Centro Phys. Des Plaumas, Eocle Pohroch, SWITERLAND

Bublothex, het. Voor Plaem-Fysica, THE NETHERLANDS

Alst Prot. Or. S. Codir, Middo Enut Tech. Univ., TURKEY

Dr. V.A. Culdhinh,Sal. Pes. Inet Enctrophys.l Apparaus, USSR

Dr. D.D. Ayutov, Siberian Branch of Academy of Sa., USSA

Dr. G.A. Eliecer, I.V. Kunchatiov Inst, USSR

Librarien, Tho Ukr.SSA Acaderny of Sciencos, USSA

Dr. LM. Kovrizhnyth, Inet of Gonord Phyrica, USSR

Komberchungeandeo GmbH, Zentrabibiothek, W. GERMANY

Bibliothek, Inst FOr Plasmalorschung, W. GERMANY

Prol. K. Sctinder, Ruhr-Univeninu Bochum, W. GERMANY

Dr. F. Weoner, (ASOEX), Mux Planck-thettut, W. GERMANY

Librerien, Max-Plenck-fnative, W. GERMANY

Prot. R.K. Janev, Inat of Phycica, rucosLakia 
DATE

FILMED

$2 / 26 / 92$ 
